\title{
PROFESORA VLADIMIRA KOSINSKA (1864-1938) DZĪVES UN DARBA GAITAS
}

\section{TATJANA FEIGMANE*,}

Latvijas Krievu kultūras mantojuma institūts

Kopsavilkums. Ekonomists Vladimirs Kosinskis (1864-1938) dzimis tagadējās Ukrainas teritorijā. Viṇš Maskavas Universitātē absolvēja divas fakultātes: Fizikas-matemātikas (1887) un Juridisko (1891). Viṇš ir pazīstamā krievu ekonomista, statistik̦a Aleksandra Čuprova skolnieks un strādājis Maskavas Universitātē, Rīgas Politehniskajā un Kijevas Politehniskajā institūtā, Odesas Universitātē, Prāgas Krievu universitātē un Latvijas Universitātē, kur profesors zinātniskajam darbam sagatavoja A. Zalı,o, K. Zīvertu, J. Vìtolu, A. Aizsilbnieku. Vladimirs Kosinskis ieguva autoritāti kā speciālists tautsaimniecības teorijā. Vairums viṇa darbu publicēti krievu valodā, latviski - viṇa lekcijas. Profesors miris 1938. gadā Rīgā un apbedīts Pokrova kapos.

Atslēgas vārdi: Vladimirs Kosinskis, Rīgas Politehniskais institūts, Latvijas Universitāte, ekonomika.

\section{Darbība Krievijas impērijā un ārzemēs}

Vairāk nekā 50 gadu Vladimira Kosinska vārds nepamatoti nav minēts zinātniskajā apritē. Bet atmiṇa par viṇu saglabājusies viṇa darbos un bijušo studentu atmiṇās, arī arhīvu dokumenti liecina par viṇa pašaizliedzīgo darbu zinātnē un augstskolas pedagoǵijā. Profesora V. Kosinska darbi bija zināmi ne tikai Eiropā, bet arī Amerikā, un kultūrvēsturiska nozīme tiem ir joprojām.

Vladimirs Kosinskis dzimis 1864. gada 25. augustā Čerṇigovas gubern,as Gluhovas apriṇ̣̂ī, tagadējās Ukrainas teritorijā, vietējā apkārtnē labi

\footnotetext{
* Korespondējošais autors.

E-pasts: t.feigmane@inbox.lv
} 
pazīstamā dižciltīgā ǵimenē. Vladimira tēvs - Andrejs Kosinskis ieṇēma guberṇas sekretāra amatu.

1883. gadā Vladimirs Kosinskis absolvēja Novgorodas Severskas gimnāziju. Kopš agrīnas jaunības viṇš izcēlās ar uzcītību mācībās. Maskavas Universitātē viṇš apguva divu fakultāšu kursu. V. Kosinskis studēja Fizikas-matemātikas fakultātes matemātikas zinātṇu nodạ̣ā (1883-1887), kuru absolvēja, iegūdams matemātikas kandidāta zinātnisko pakāpi, un Juridiskajā fakultātē (1887-1891), kuru absolvēja ar 1. pakāpes diplomu [1].

Krievijā strādājošie V. Kosinska zinātniskās darbības pētnieki I. Jeḷisejeva un A. Dmitrijevs Krievijas Valsts vēstures arhīvā, Maskavas Universitātes Juridiskas fakultātes dokumentos ir atraduši viṇa raksturojumu, ko bija sagatavojis pazīstamais krievu ekonomists un statistikis Aleksandrs Čuprovs (1842-1908): «Savas darbības laikā Juridiskajā fakultātē viṇš [Kosinskis] $]^{1}$ kopš paša sākuma interesējās par politekonomiju un statistikas teoriju, īpaši par tām statistikas sadaḷām, kur bija saskarsme ar matemātiku». Viṇa darbs «Par zinātniskās izstrādes paṇēmieniem...» atklāja autora lielo erudīciju, izcilas spējas un nopietnu iedziḷināšanos pētāmajā disciplīnā un «prasmi izmantot matemātikas metodes sabiedrisko zinātṇu jautājumu risināšanā». [..] «Pilnībā protot trīs - vācu, franču un angḷu - valodas un atšķirdamies ar lielisku darba mīlestību, Kosinskis jau universitātes laikā ieguva visai plašas zināšanas ekonomikas un statistikas jautājumiem veltītajā literatūrā, tā ka viṇa turpmākais darbs būs tikai iepriekš iesāktās nodarbes turpinājums.» [2]. 1894. gadā V. Kosinskis piedalījās krievu dabas pētnieku un ārstu IX kongresa statistikas apakšsekcijas darbā. 1894. gadā Čerṇigovā viṇa redakcijā tika izdoti šĩs apakšsekcijas dalībnieku darbi. Tajā laikā V. Kosinska zinātnisko interešu sfēra, acīmredzot A. Čuprova ietekmē, mainìjās vin,u sāka interesēt lauksaimniecības ekonomikas problēmas [2].

Kā viens no labākajiem absolventiem V. Kosinskis tika atstāts darbam Maskavas Universitātē, lai Politiskās ekonomijas un statistikas katedrā varētu sagatavoties profesūrai un iegūt zinātnisko grādu. 1895.-1896. gada janvārī Vladimirs Kosinskis tika nosūtìts zinātniskajā komandējumā uz ārzemēm. Tã laikā viṇš strādāja Parīzes, Berlīnes, Londonas un Drēzdenes universitātēs un bibliotēkās, gatavojoties aizstāvēt disertāciju par kreditēšanas teoriju. Vairāk nekā gadu jaunais zinātnieks strādāja Britu Muzeja bibliotēkā.

Pēc atgriešanās no ārzemju komandējuma V. Kosinskis 1900. gadā tika piennemts darbā par privātdocentu Maskavas Universitātē. 1901. gada 31. maijā viṇš publiski aizstāvēja disertāciju: «Учреждения для мелкого кредита в Германии. Их история в связи с некоторыми сторонами экономической жизни этой страны» («Mazā kredīta

1 Autores precizējums. 
iestādes Vācijā. To vēsture saistībā ar dažām šīs zemes ekonomiskās dzīves norisēm») un pēc Maskavas Universitātes Padomes lēmuma viṇš ieguva politekonomijas maǵistra grādu [3]. Tajā pašā gadā Vladimiru Kosinski norīkoja strādāt Rīgas Politehniskajā institūtā (RPI), kurā tolaik trūka politekonomijas speciālistu un kas atradās toreizējās Krievijas impērijā [4]. Tomēr pirmais Rīgas laikposms V. Kosinska dzīvē nebija ilgstošs, bet, domājams, piemin,as vērts. Sākumā vinš bija docents, bet 1902. gada 1. janvārī politekonomijas maǵistrs V. Kosinskis tika iecelts par RPI politekonomijas kursa adjunktprofesoru. Pēdējā dokumentā saistībā ar V. Kosinska darbu Rīgā (tas ir datēts 1904. gada 8. aprīlī) rakstīts par viṇa pāriešanu darbā Odesas (Novorosijskas jeb Jaunkrievijas) Universitātē. Lēmums par viṇa apstiprināšanu ekstraordinārā profesora amatā tika pien,emts 1904. gada 19. martā, bet sarakste par vina pāriešanu darbā uz Novorosijsku sākās jau 1903. gadā [5].

Kas bija par iemeslu V. Kosinska tik drīzai aizbraukšanai no Rīgas? Strādājot Rīgā, viṇš bija iepazinies ar vietējo agrāro iekārtu, saskaṇā ar kuru lielākā zemesgabalu daḷa atradās vācu baronu īpašumā; viṇš atzina šāda stāvokḷa netaisnīgumu un kḷūdainību, vadoties no ekonomiskā viedokḷa. Pēc viṇa domām, par lielākiem zemes turētājiem vajadzēja būt latviešu zemniekiem. Savas domas viṇš neslēpa un sakarā ar to arī zaudēja vietu RPI, un bija spiests pārcelties uz Odesu. Pirmsrevolūcijas laikā V. Kosinska uzskati agrārajā jautājumā tika kritizēti ne tikai no labējo (kā tas bija Rīgā), bet arī no kreiso puses. Viṇa viedoklis par zemnieku saimniecību attīstības perspektīvām radīja arī lielinieku līdera Vladimira Uḷjanova (Ḷen,ina) neapmierinātību, jo viṇš Kosinska uzskatos saskatīja šḳiru cīnnas norimšanas draudus laukos [6].

Odesā Vladimirs Kosinskis nostrādāja piecus gadus - sākumā par ekstraordināro profesoru, bet kopš 1905. gada viṇš kḷuva par universitātes Juridiskās fakultātes dekānu [7]. 1907. gadā V. Kosinskis iesniedza Maskavas Universitātes Juridiskajā fakultātē savu disertāciju: «Крестьянское и помещичье хозяйство» («Zemnieku un muižas saimniecība») un 1907. gada 9. marta publiskajā sēdē to sekmīgi aizstāvēja, iegūstot ekonomikas un statistikas doktora zinātnisko grādu. 1909. gadā V. Kosinskis bija spiests atstāt Odesu, jo vin,a politiskie uzskati tika uztverti par pārāk kreisiem. Tajā pašā gadā viṇš sāka strādāt par ordināro profesoru Kijevas Politehniskajā institūtā un Kijevas Komercinstitūtā [8]. 1912. gadā tika atzīmēta Rīgas Politehniskā institūta 50 gadu jubileja, un V. Kosinskis bija ieplānojis piedalīties svinībās, taču neparedzētu apstākḷu dēḷ viṇš nevarēja ierasties Rīgā un apsveica augstskolu ar telegrammas starpniecību [9].

Pirmsrevolūcijas periods Vladimiram Kosinskim ir visai auglīgs. Šajā laikā galvenie viṇa darbi ir: «Par statistikas datu zinātniskas izstrādes paṇēmieniem» (1890); «Par agrāro jautājumu», 1. laidiens; «Zemnieka un 
muižas saimniecība» (1906; doktora disertācija); «Eksaktās zināšanas un sabiedriskās zinātnes» (1903); «Par pasākumiem ražošanas spēku attīstībai Krievijā» (1904); «Par agrāro jautājumu», 2. laidiens; «Parādi par zemi un zemes īpašuma mobilizācija» (1914) u. c. Šajā laikā V. Kosinskis piedalījās arī Brokhauza un Efrona enciklopēdiskās vārdnīcas sastādīšanā [10].

Oktobra revolūciju (jeb lielinieku apvērsumu) profesoram nācās pārdzīvot Kijevā. Pēc Krievijas zinātnieku I. Jeḷisejevas un A. Dmitrijeva atzinuma, «1917. gada notikumi tieši ietekmēja Kosinska likteni. 1917. gada oktobrī no kadetu partijas viṇu ievēelēja par Krievijas republikas Pagaidu padomes (Priekšparlamenta) locekli. Šajā laikā viṇš sagatavoja «Ziṇojumu agrārajā jautājumā» (Kijeva 1918), kurā bija izklāstīti toreizējos apstākḷos galvenie agrārā jautājuma risināšanas principi. Pēc Kosinska uzskatiem, šī jautājuma risināšanas politiskā nozīme pilnībā ir balstīta tā sociālekonomiskajā racionalitātē - agrārā jautājuma risināšanas pasākumi var gūt noturīgus politiskus panākumus tikai tad, ja tiem būs labvēlīgas sociālekonomiskas sekas. Agrārais jautājums jārisina ne no kādas šḳiras interešu viedokḷa, bet gan no nacionālā - visas valsts - izdevīguma viedokḷa. Par vienu no svarīgākajiem agrārās reformas īstenošanas principiem Kosinskis minēja atlīdzināšanas principu, t. i., nepiel̦aut zemes atsavināšanu un konfiscēšanu bez atlīdzības. Visām zemēm jābūt pārdotām. Turklāt galvenais viṇam bija privātīpašuma princips - «privātīpašuma tiesības pilnīgi jāatjauno, jāīsteno un jāgarantē no visdažādākajiem satricinājumiem, kas pēdējā laikā bijuši pārpārēm». Viṇš norādīja, ka «stingra un nelokāma tiesību uz zemes privātīpašumu ieviešana dzīvē būs iespaidīgs tiesību un kārtības izplatītājs anarhistiski noskaṇotajās lauku iedzīvotāju masās» [11].

1918. gadā Kosinski iekḹāva komisijas sastāvā, kuras nolūks bija izstrādāt likumprojektu par Ukrainas Zinātṇu akadēmijas nodibināšanu un vinuu kā vienu no pirmajiem ievēlēja par tās akadēmiķi Sociālo zinātṇu nodạ̣ā.

1918. gadā V. Kosinskis ieñema darba ministra biedra amatu hetmaña P. Skoropadska (1873-1945) valdībā, bet pēc šīs valdības krišanas 1918. gada beigās V. Kosinskis apmetās uz dzīvi Varšavā, kur kādu laiku vadīja Krievu akadēmisko grupu Polijā [11]. Par V. Kosinska dzīves posmu no 1919. gada līdz 1921. gadam zinuu ir maz. 20. gadu sākumā V. Kosinskis ar bēgḷu straumi nonāca Konstantinopolē, taču tur viṇš ilgāku laiku nepalika.

Jauns V. Kosinska darbības posms sākās 1922. gadā - tolaik viṇš ieṇēma ordinārā profesora amatu jaundibinātās Krievu Juridiskās fakultātes Politekonomijas un statistikas katedrā Prāgā. Paralēli tam viṇš strādāja arī Čehu Komercinstitūtā un citās mācību iestādēs.

Krievu Juridiskās fakultātes politekonomijas seminārā V. Kosinskis veica loti aktīvu darbu ar dažādu fakultāšu un kursu studentiem: 
studējošie izstrādāja jautājumus par Krievijas tautsaimniecības atdzimšanas finanšu un ekonomiskām problēmām. Prāgā krievu valodā tika izdoti «Politekonomijas pamatu» trīs sējumi, šos jautājumus V. Kosinskis pastiprināti pētīja un izstrādāja vēl savas darbības Kijevas posmā, kā arī iznāca viṇa «Lekcijas politiskās ekonomijas teorijā» (1922). Savos darbos par agrāro jautājumu V. Kosinskis centās pierādīt, ka Krievijas Eiropas daḷā lielākā daḷa zemes (pirmsrevolūcijas laikā) piederēja zemniekiem nevis muižniekiem vai citu kārtu pārstāvjiem [11].

\section{Darbs un dzive Latvijas Republikā (1928-1938)}

1928. gadā Vladimirs Kosinskis pieñēma lēmumu aizbraukt no Prāgas un pārcelties uz Rīgu, pilsētu, kas viṇam bija labi pazīstama un kur bija iespēja dabūt piemērotu darbu. 1928. gada 24. maijā LU Tautsaimniecības un tieslietu fakultātes sēdē V. Kosinskis uz pieciem gadiem tika ievēlēts par kooperācijas kursa ārštata profesoru, kaut gan tobrīd viṇš vēl dzīvoja Prāgā. 1928. gada 28. jūnijā Ministru kabinets apstiprināja viṇa ievēlēšanu par LU ārštata profesoru, un šajā amatā vin,š skaitījās no 1. jūlija [12, 13]. 1928. gada 25. augustā Latvijas Ģenerālkonsulāts Čehoslovakijā izdeva iebraukšanas vīzas nansenistiem - Vladimiram Kosinskim, viṇa sievai un diviem bērniem. Iebraucot Latvijā, viṇiem tika izsniegtas personu apliecības [14-18]. Kosinsku gimene apmetās Pārdaugavā, nelielā dzīvoklī Lapu ielā.

LU Tautsaimniecības un tieslietu fakultātes vadība jau pirmajos darbības mēnešos uzticēja V. Kosinskim vadīt seminārus pa divām stundām nedēlāa tautsaimniecības teorijā un ekonomiskajā geogrāfijā. 1932. gada oktobrī Tautsaimniecības un tieslietu fakultātes sēdē V. Kosinskis vienbalsīgi tika ievēlēts par štata profesoru. Turklāt fakultāte iesniedza lūgumu atḷaut profesoram lasīt lekcijas vācu valodā, kaut gan tolaik tika izvirzītas prasības lasīt lekcijas un rīkot seminārus tikai latviešu valodā [19].

1934. gada 31. maijā Vladimirs Kosinskis vērsās LR Iekšlietu ministrijas Administratīvajā departamentā ar lūgumu uzṇemt viṇu un viṇa ǵimenes locekḷus Latvijas pavalstniecībā. Par iemeslu savai vēlmei vinš̌ minēja labas attiecības ar bijušajiem Rīgas Politehniskā institūta kolēgiem un studentiem, 15 zinātnisko darbu sējumus, kā arī to, ka viňš gatavo trīs asistentus doktora disertācijas aizstāvēšanai [20]. Anketā viṇš atzīmēja, ka brīvi pārvalda krievu, vācu, franču, angḷu un itāḷu valodas. Tajā pat laikā norādīja, ka neprot latviešu valodu [21]. Acīmredzams ir fakts, ka minētais lūgums bija saistīts ar aiziešanu pensijā tuvākajā laikā.

1934. gada 20. jūlijā profesors V. Kosinskis lūdza iekšlietu ministru paātrināt lēmumu par viṇa un viṇa ǵimenes locekḷu uzṇemšanu Latvijas 
pavalstniecībā. Minēto lūgumu atbalstīja Tautsaimniecības un tiesību zinātṇu fakultātes dekāns Jānis Kārkliṇš (1877-1955) [22], RPI absolvents, kurš sāka studēt 1903. gadā, tātad laikā, kad V. Kosinskis vēl strādāja un dzīvoja Rīgā. 1935. gada 10. septembrī profesors V. Kosinskis nodeva zvērestu par uzticību Latvijas valstij [23]. Vienlaikus Latvijas pavalstniecībā tika uzṇemta viña dzīvesbiedre un dēls Vladimirs.

Dažas problēmas bija ar meitas Tatjanas Kosinskas uzṇemšanu Latvijas pavalstniecībā. Par škēērsli tam bija viñas dalība Krievu Pareizticīgo studentu vienībā (1928-1934), kas tika atzīta par kaitīgu valstij un sabiedrībai [24]. Bet galu galā Iekšlietu ministrijas Politiskā pārvalde neiebilda pret T. Kosinskas uzñemšanu par Latvijas pilsoni. 1935. gada 19. decembrī viña ieguva Latvijas pavalstniecību un 1936. gada 3. februārī nodeva zvērestu [24]. 1936. gadā V. Kosinskis tika pārcelts par ārštata profesoru. Fakultāte lūdza LU rektoru ieskaitīt V. Kosinskim viṇa pensijas stāžā darbu ārzemju augstākajās mācību iestādēs, kā arī prasīja atḷaut viṇam vēl dažus gadus strādāt par ārštata profesoru, jo viṇš gatavoja habilitācijai divus fakultātes asistentus: Jāni Vìtolu tautsaimniecības teorijā un Arnoldu Aizsilnieku tautsaimniecības teorijā un mācībā par kooperāciju. Pateicoties V. Kosinska prasmīgai vadībai, abi šie absolventi jau bija ieguvuši Rokfellera stipendiju studijām ārzemēs un iesnieguši fakultātei savus habilitācijas darbus. V. Kosinskis bija sagatavojis zinātniskam darbam vēl divus fakultātes beidzējus: Arnoldu Zạ̣o tautsaimniecības teorijā un Kārli Zīvertu statistikā.

Tautsaimniecības un tieslietu zinātṇu fakultāte deva profesoram iespēju pabeigt tautsaimniecības teorijas kursa sastādīšanu, lai to varētu izdot. Šis darbs tika iecerēts ne tikai kā mācību grāmata studentiem, bet gan kā gara mūža novērojumu un vērtējumu kopojums noteiktā saimnieciskā sistēmā, tam vajadzēja kḷūt par pamatu noteikta dzīves uzskata veidošanai. No darba bija gatavas apmērām divas trešdaḷas - ap 1000 lpp. latviešu valodā [25].

Fakultātes lūgums tika atbalstîts, un V. Kosinska audzēkṇi (viṇu vidū A. Aizsilnieks) lūdza piešksirt profesoram Kultūras fonda stipendiju, lai viņš varētu izdot monogrāfiju «Основы народного хозяйства» («Tautsaimniecības pamati») latviešu valodā [25]. Par to tika saṇemtas pozitīvas atsauksmes ar priekšlikumu izdot V. Kosinska minētā darba 1. sējumu 1000 eksemplāru tirāžā, jo šĩ grāmata varētu ieinteresēt ne tikai studentus, bet arī daudz plašāku publiku. Atsauksmi deva arī toreizējais vecākais docents Vilis Vītols (1. attēls), RPI 1908. gada absolvents, atzīstot tās izdošanu par «ḷoti vēlamu un atbalstāmu» [26]. 1936. gada 12. novembrī viens no profesora kolēǵiem, jau minētais toreizējais LU vecākais docents Jānis Kārkliṇš, aizstāvēja disertāciju «Latvijas tirdzniecības kuǵniecība», iegūstot ekonomisko zinātṇu doktora grādu. Oponenti J. Kārkliṇa darbam bija trīs: V. Kosinskis, E. Birkhāns un V. Vītols [27]. 
par prof. $\nabla . K$ o s i n $\mathrm{k}$ a darbu " Tautsaimniecības mācības pamiati" pirmo sējumu.

Augšminetā darba pirmais sējums iedalīts trijās dąās, ar tālāku iedalijumu nodalās, paragräfos un burtos. Pirmā dałā - ievadā, trijās nodalās pamatīgi iztirzāti jautājumi par sabiedrību, par sociālo parādību likumveidību , saimniekojošo sabiedrību un beidzot iztirzāts jautājums par tautsaimniecības mācības objektu, uzdevumiem un pētīsanas metodēm.Autors nosauc tautsainiecības mācību par"zinātni par saimniekojošo sabiedrību", un saka, ka క̌̃ definīcija esot plašāka par parasto šīs māoības definīciju.

Aplūkojot uzskatus par sabiedrību pēc Spensera,Stamlera un Simmela, autors noraida pirmos divus, norādot, ka uz minetās bāzes tie nav uzbūrējuši pozitīvu tautsaimniecības teorijas sistēmu, un nāk pie slēdziena, ka "bez individa un bez vina konkretām individuelām intresêm un vajadzībām nav iespējams izskaidrot pat to, kā izcelas vienreizējs mainas akts, un jo vairāk nav iespējams izskaidrot tautsaimniecības mainas apgrozību, konjunktūru, krīzes un t.t., papildina Simmela sabiedrības definējumu, ka"sabiedrība ir to. personu kopība,kuras atrodas savstarpīgās faktiski psíchiskâs attiecĩbās"divi virzienos - no vienas puses - aizrādot uz sebiedrības iekārtas lielo nozīmi, no otras puses - ảizrādot uz sociālo parādību likumvedību, iztirzājot šo jautājumu jo plaši otrā nodalā, nemo' vērā pasaules literatūrā pazistamos darbus, ka par piem., llilla, Čuprova, Rickerta, Vindelibanda, Sigvarta, Šmollera, Vāgnera, Buechera, Mengera, Brentāno, Boem-Baverka, Dīla, Lĩfmana, Sulca-Gevernica, Stammlera, Ketele, Maxvela, Bertrana, Dževonsa un daudzu citu darbus.

Definējot individa"darbību, kuras nolūks ir ārejas pasaules priekšmetus pielägot cilvēku vajadzībām un tos patērēt"par_saimniecisku_ darbịbu. autors "ar sabiedrības sainniecisko darbību saprot saimniєkojošo sabiedrību sastāditāju individu darbību, kuras nolūks ir ārejās pasanles priekšmetus pielägot cilvēku vajadzībān un tos patērēt!no tā tad arī izriet saimniekojošăs sabiedrības jēdziens, pie kam saimniekojošo sabiedrību autors sadala divu ketegoriju organizācijās: uzp̣ēmumos un mājsaimniecībā. Definējot uzpēemumu, kä "individu vaj individu grupu, kas apvienojušies uz viena vaj otra pamata, lai izdarītu vajadzīgās manipulācijas pie ärejās nasaules priekšmetị̂m, laì tos pielāgotu cilvēku vajadzībām";autors atzīst kä svarīgus trīs uznēmumu tipus - kapatalistisko, darba un publiski-tiesisko uzpēmumus, raksturojot tos katru par sevi noteiktām pazīnēm. Tamdēz, par tautsaimniecības mācības objektu autors uzlūko saimniekojošãs sabiedrības darbību un tās

1. attēls. Fragments no LU vecākā docenta Viḷa Vītola atsauksmes par V. Kosinska darba «Tautsaimniecības mācības pamati» 1. sējumu, 1938. g. 18. maijā [26]. 


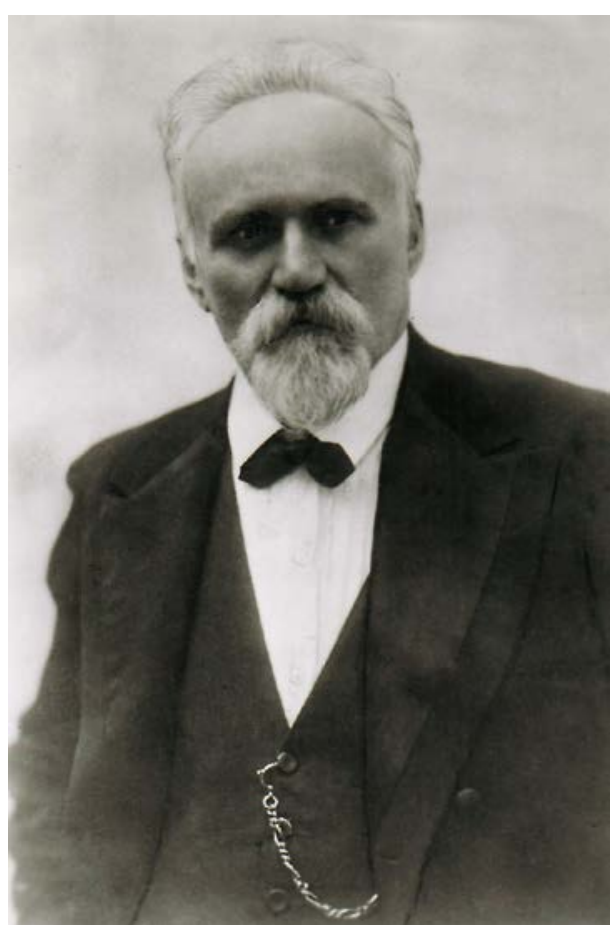

2. attēls. Profesors Vladimirs Kosinskis (1864-1938) 20. gadu beigās. Fotoattēls no V. Kosinska mazmeitas Marinas Kosinskas personīgā arhīva.

Tas liecina, ka Vladimirs Kosinskis bija iemantojis pelnītu autoritāti Latvijas akadēmiskajās aprindās un savā nozarē bija neaizvietojams speciālists. V. Kosinska plašo tautsaimniecības teorijas kursu no krievu valodas latviešu valodā 20. gadsimta 30 . gados daḷeji bija iztulkojis asistents A. Zalıiais [28]. Minētā grāmata neiznāca nedz krievu, nedz latviešu valodā. Latviski ir izdotas vien profesora LU 1930./1931. mācību gadā lasītās lekcijas tautsaimniecības teorijā [29]. LU bibliotēkā glabājas daḷa profesora krievu valodā ārzemēs izdoto grāmatu.

Smaga slimība un nāve 1938. gada 5. novembrī aprāva zinātnieka dzīves pavedienu, kā arī nedeva Vladimiram Kosinskim iespēju īstenot savas ieceres [30].

«Viṇš piederēja to cilvēku skaitam, kuriem allaž un visos apstākḷos visaugstāk un visvērtīgāk ir kalpot zinātnei, zinībām un cilvēces gaišajiem ideāliem», tā rakstīts nekrologā, Vladimiram Kosinskim mūžībā aizejot. Sēru dievkalpojums notika Rīgas Svētās Trijādības sieviešu klostera dievnamā. Pēc tam bēru procesija devās uz Pokrova kapiem, kuru vārtos to sagaidīja Pokrova dievnama draudzes virspriesteris G. Ponomarjovs un diakons I. Gonestovs [31]. 


\section{Profesora gimene}

Vladimirs Kosinskis apprecējās 19. gadsimta beigās, uzturoties Berlīnē. Vinu Sv. Kṇaza Vladimira baznīcā pie Krievijas vēstniecības salaulāja ar dzimtmuižnieci Jel̦enu Karatiginu. Kosinsku ǵimenē bija trīs bērni. Par profesora Kosinska vecāko dēlu Andreju, dzimušu 1897. gadā, ir zināms, ka 1934. gadā vinšs dzīvojis Argentīnā [32].

1903. gada 26. augustā Rīgā Kosinsku ǵimenē piedzima meita, kura 28. septembrī tika kristīta Rīgas Katedrālē un nosaukta par Tatjanu. Meiteni kristīja virspriesteris Vladimirs Pliss [33]. 1928. gadā Tatjana kopā ar vecākiem un jaunāko brāli Vladimiru pārcēlās uz dzīvi Latvijā, kur kḷuva par aktīvu Krievu Pareizticīgo studentu vienības locekli [34], vēlāk viṇa savu aicinājumu atrada ikonu glezniecībā. 1937. un 1938. gadā Tatjana Kosinska kārtoja ārzemju pasi braucienam uz Palestīnu, lai tur nodarbotos ar dievnamu apgleznošanu. 1940. gada 17. februārī Tatjana Kosinska saṇēma ielūgumu no Berlīnes bīskapa Sergija pabeigt iesākto Sv. Vladimira baznīcas apgleznošanu [35]. Domājams, ka Latvijā viṇa vairs neatgriezās. Otrā pasaules kara gados viṇa nodarbojās ar ikonu glezniecību Prāgā un vadīja restaurācijas darbus Vissvētās Dievmātes Aizmigšanas baznīcā Oḷšanskas kapsētā. Pēc 1945. gada viṇa dzīvoja Anjerā Parīzes tuvumā, kur tika uzṇemta mūḳenu kārtā ar Serafimas vārdu. 1958. gadā mūksene Serafima pārcēlās uz ASV, kur turpināja nodarboties ar dievnamu apgleznošanu. Viṇas mūžs noslēdzās Kalifornijā 1981. gadā [36]. Jaunākais profesora dēls Vladimirs dzimis 1908. gada 15. oktobrī Černigovas guberñā. 1928. gadā viṇš iestājās Latvijas Universitātē, ko vinšs sekmīgi absolvēja 1935. gadā, iegūdams ārsta terapeita diplomu. No 1935. gada viṇš strādāja Latvijas Universitātes Medicīnas fakultātē [37]. Pēc Otrā pasaules kara līdz savai nāvei 1959. gada 12. augustā V. Kosinskis juniors strādāja par ārstu rentgenologu Valsts klīniskajā slimnīcā (patlaban - Paula Stradiṇa Klīniskā universitātes slimnīca).

Pēc profesora nāves atraitne Jel̦ena Kosinska vērsās LR Tautas Labklājības ministrijā ar lūgumu piešķirt vinai pensiju par vinssaulē aizgājušo vīru. No ministrijas tika saṇemta atbilde, ka profesora Kosinska pensijas izdienā ieskaitāmi 35 gadi. Ja profesors būtu dzīvs, viñam būtu aprēķināta pensija $80 \%$ no algas $(740,00 \mathrm{Ls})$, bet atraitnei pienākas 40 \% no algas, t. i., 296,00 Ls. Ar padomju varas ienākšanu Latvijā 1940. gada profesora kundzes mēneša pensija tika samazināta - viṇa saṇēma vien 70 rublus [38]. 


\section{AVOTU UN LITERATŪRAS SARAKSTS}

[1] Latvijas Valsts vēstures arhīvs (turpmāk LVVA), 7175. f., 1. apr., 167. l., 4. lp.

[2] Jelisejeva, I. I., Dmitrijev, A. L. V. A. Kosinskij - vidnij otezhestvennij statistik i ekonomist. Voprosi Statistiki, 2011, Nr. 4, S. 77.

[3] LVVA, 7175. f., 1. apr., 167.l., 5. lp.; 7427. f. 13. apr., 851. 1., 84.-85. lp.

[4] Album Academicum Rizhskovo Politehnizheskovo instituta, 1862-1912. Riga: Jonck \& Poliewsky, 1912, S. 703.

[5] LVVA, 7175. f., 1. apr., 165.l., 6., 7., 10., 11., 15.-19., 23., 45.-46. lp.

[6] Lenin, V. I. Polnoje sobranije sozhinenij. 5-je izdanije. Moskva: Politizdat, 1971, t. 23, S. 433-434; t. 24, S. 5.

[7] Latvijas Universitāte, 1919-1929. Rīga: LU, 1929, 536.-537. lpp.

[8] LVVA, 7427. f., 13. apr., 851. l., 84.-85. lp.

[9] Kratkoje opisanije porjadka 50-letnevo jubileja Rizhskovo Politehnizheskovo instituta v oktjabrje 1912 g. Riga: 1912, S. 98.

[10] Brokgauz, F. A., Efron, I. A. Enciklopedizheskij slovar, t. 6, S. 258 Moskva: 1997, nauzhnoje izdatelstvo «Bolshaja Rossijskaja enciklopedija», издательский дом «Ekonomizheskaja gazeta».

[11] Jelisejeva, I. I., Dmitrijev, A. L. V. A. Kosinskij - vidnij otezhestvennij statistik i ekonomist. Voprosi Statistiki, 2011, Nr. 4, S. 79.

[12] Latvijas Universitāte divdesmit gados, 1919-1939. II. Rīga: LU, 1939, 528.529. lpp.

[13] LVVA, 7427. f. 13. apr., 851. 1., 3., 6., 14.-15. lp.

[14] LVVA, 3234. f., 24. apr., 7174. 1., 1. lp.

[15] LVVA, 2996. f., 10. apr., 37600. l, 1. lp.

[16] LVVA, 2996. f., 10. apr., 37589. 1., 1. lp.

[17] LVVA, 2996. f., 10. apr., 37597. 1., 1. lp.

[18] LVVA, 2996. f., 10. apr., 37601. l., 1. lp.

[19] LVVA, 7427. f. 13. apr., 851. 1., 36. lp.

[20] LVVA, 3234. f., 2. apr., 25193. 1., 1-3. lp.

[21] Turpat, 19. lp.

[22] Turpat, 24. lp.

[23] Turpat, 73.-74. lp.

[24] Turpat, 78.-79., 87., 89. lp.

[25] LVVA, 7427. f. 13. apr., 851. 1., 47., 53., 87. lp.

[26] Turpat, 89.-90. lp.

[27] Baltiņš, M. Latvijā aizstāvētās doktora disertācijas (1923-1944). Bibliogrāafisks rādītājs. Rīga: LU, 2004, 70. lpp.

[28] Adamovičs, L. Zinātne tēvzemei divdesmit gados, 1918-1938. Rīga: LU, 1938, 279. lpp.

[29] Kosinskis, V. Tautsaimniecības teorija: V. Kosinska lasītais kurss 1930/31. akad. gadā Latvijas Universitātē. Rīga: B. i., 1930, 53. lpp.

[30] Umer prof. V. A. Kosinskij. Segodnja, 1938, Nr. 307, S. 6.

[31] Na pogrebenii prof. V. A. Kosinskovo. Segodnja, 1938, Nr. 308, S. 4. 
[32] LVVA, 3324. f., 2. apr., 25193. l., 19. lp.

[33] Turpat, 4.lp.

[34] Turpat, 52.-54. lp.

[35] LVVA, 3234. f., 24. apr., 7174. 1., 1., 3.-5. lp.

[36] Istorija arhitekturi russkovo zarubezhja [tiešsaiste]. [Skatīts 2017. g. 31. martā.] Pieejams: http://www.artrz.ru/search/Косинская/180490 4084.html.

[37] LVVA, 7427. f., 13. apr., 852. l., 1.-4.lp.

[38] LVVA, 5213. f., 3. apr., 717. l., 1., 8., 12. lp.

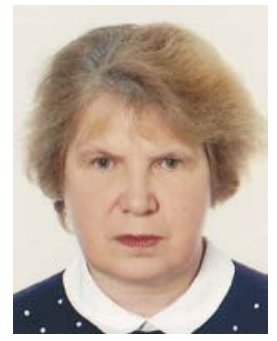

TATJANA FEIGMANE, Dr. hist., has been a teacher at schools and a lecturer at universities. She was the manager of the project «Latvian Russians». Her main academic interests include the history of Russians in Latvia, their schools, organisations etc.

Phone: +37129517470

E-mail: t.feigmane@inbox.lv

Tatjana Feigmane

\section{Professor Vladimir Kosinski’s (1864-1938) Life and Work}

Professor Vladimir Kosinski (1864-1938) is a well-known statistician and economist. He was born in a noble family in the province of Chernigov. After graduating from the Gymnasium, he entered the University in Moscow where he was a student at two faculties: the Faculty of Physics and Mathematics (1887) and Faculty of Law (1891). He studied also abroad. In 1900, Vladimir Kosinski was appointed a privatdocent at Moscow University; from 1901 to 1904, he was an Adjunct Professor with the Riga Polytechnic Institute and from 1904 to 1909 - an Extraordinary Professor of the Odessa Polytechnic Institute. In 1907, he defended his Thesis at Moscow University and received the scientific degree of Doctor of Economics and Statistics. From 1909 to 1919, he was a Professor with the Kyiv University of St. Vladimir; from 1922 to 1928 - a Professor with the Russian Law Faculty in Prague (Czechoslovakia); from 1928 to 1938 - a Professor with the Department of Economy and Law of the University of Latvia. From 1936, he was a freelance professor. He died in 1938 in Riga, Latvia. During his long career of professorship, Kosinski prepared many brilliant specialists, among them the well-known Latvian scientist Arnolds Aizsilnieks (1898-1982), and is the author of numerous scientific works.

Keywords: Vladimir Kosinski, Riga Polytechnic Institute, University of Latvia, economics. 
Жизнь и деятельность профессора Владимира Косинского (1864-1938)

Экономист, специалист в области политэкономии В. Косинский родился на территории нынешней Украины. В Московском университете он окончил два факультета: отделение математических наук Физико-математического факультета (1887) и Юридический факультет (1891). Он был учеником известного русского экономиста, статистика Александра Чупрова и работал в Московском университете (1900-1901), в Рижском политехническом институте (1901-1904), в Одесском университете (1904-1909), затем в Киевском политехническом институте, с 1922 года - на вновь созданном Русском юридическом факультете в Праге. В 1928 году приехал в Ригу и стал работать профессором Латвийского университета (до 1938 года). Его основные научные работы по народному хозайству опубликованы на русском языке, на латышском - лишь его лекции. Профессор умер 5 ноября 1938 года и похоронен на Покровском кладбище в Риге.

Ключевые слова: Владимир Косинский, Рижский политехнический институт, Латвийский университет, экономика. 